\title{
PERKEMBANGAN ONTOGENETIK DAUN TANAMAN KARET SEBAGAI PENANDA AWAL ADAPTASI TERHADAP CEKAMAN LINGKUNGAN DAN PATOGEN
}

\author{
Leaves Ontogenetical Development as Early Marker \\ of Environmental Stress and Pathogen Adaptability on Rubber Plant \\ Junaidi dan Atminingsih \\ Balai Penelitian Sungei Putih, Pusat Penelitian karet \\ Po. Box 1415 Medan 20001, Telp. +6261 7980045 \\ Email : atminingsih85@gmail.com
}

Diterima 14 Juni 2016 / Direvisi 18 April 2017 / Disetujui 28 April 2017

\begin{abstract}
Abstrak
Daun karet bervariasi antar klon dalam hal bentuk, ukuran, morfologi dan anatomi. Stadia perkembangan daun karet dapat dibedakan menjadi fase $\mathrm{A}, \mathrm{B}, \mathrm{C}$ dan $\mathrm{D}$. Pada fase $A$, anak daun menggantung vertikal terhadap tangkai daun. Pada fase B daun berwarna coklat kehijauan cerah dan bertekstur lembut. Pada fase $\mathrm{C}$ anak daun hampir tumbuh sempurna dan helaian daun tegak. Pada fase D anak daun telah berkembang sempurna mendekati horizontal terhadap tangkai daun. Secara fisiologis fase A dan B bersifat sink, sedangkan fase $\mathrm{C}$ dan $\mathrm{D}$ merupakan source. Transisi yang lebih cepat dari fase daun sink ke source pada daun baru merupakan respon penting terhadap cekaman lingkungan dan patogen. Oleh sebab itu, perkembangan ontogenetik daun dapat digunakan sebagai penanda awal kemampuan tanaman beradaptasi terhadap lingkungan dan patogen. Penelitian sejenis perlu dilakukan dengan objek klon-klon dan kondisi lingkungan yang spesifik di Indonesia.
\end{abstract}

Kata kunci: Hevea brasiliensis, daun, perkembangan ontogenetik, karakteristik fisiologi, cekaman lingkungan, patogen

\footnotetext{
Abstract

Clonal rubber leaves hadvariatedin shape, size, morphology and anatomy. The leaves development stages could be distinguished as $A, B, C$ and $D$
}

phases. In stage $A$, the leaflet hanging vertically toward petiole. In phase $B$ their color are light brown green with soft texture. In phase $C$, the leaflets are almost fully growth with straighten laminae. In phase $D$, the leaflets have fully developed in nearly horizontal position. Physiologically, phase $A$ and $B$ to be sink while phase $C$ and $D$ to be source. The shorten transition from sink to be source on new leaves is important responsed to environmental stress and pathogen. Therefore, leaves ontogenetical development couldbe used as early marker of plant adaptability to environment and pathogen. The similar researched necessary to be conducted using clones and specificenvironmentconditions in Indonesia.

Keywords: Hevea brasiliensis, leaves, ontogenetical development, physiological characteristics, environmental stress, pathogen

\section{Pendahuluan}

Daun tanaman karet (Hevea brasiliensis Muell. Arg.) umumnya terdiri dari tiga anak daun, meskipun beberapa klon baru ada yang memiliki empat anak daun. Helaian daun memiliki permukaan yang berbeda antara permukaan atas dan bawah (dorsiventral), yaitu permukaan atas lebih gelap dan mengkilap, sedangkan permukaan bawah terlihat terang dan tidak mengkilap (Gomez, 1982). Bentuk, ukuran, serta anatomi daun sangat bervarisi pada masing-masing klon (Martins and Zieri, 2003) dan digunakan sebagai salah satu parameter dalam identifikasi klon. Perbedaan signifikan antar 
klon dilaporkan terdapat pada kerapatan stomata, jumlah sel pada permukaan atas, ketebalan daun, jaringan palisade, dan lapisan spons, serta rata-rata jumlah sel per unit panjang jaringan palisade (Gomes and Hamzah, 1980). Tanaman karet dewasa menggugurkan daunnya setahun sekali (deciduous). Selama periode pembentukan daun baru produksi lateks akan mengalami penurunan tajam karena daun dan tunas tumbuh dan berkompetisi dengan biosintesis lateks dalam penggunaan fotoasimilat (Righi and Bernardes, 2008; Oktavia dan Lasminingsih, 2010).

Ontogenetik adalah riwayat pertahapan pertumbuhan dan perkembangan individu mulai dari embrio sampai dewasa (Rifa'i, 2004). Perkembangan ontogenetik daun dimulai ketika tunas baru muncul sampai daun terbentuk sempurna secara fisik dan fisologis. Secara fisik, perkembangan daun dapat dilihat dari pertambahan ukuran dan perubahan warna, sedangkan secara fisiologis umumnya dikaitkan dengan kemampuan fotosintesis. Perkembangan daun karet memiliki tahapan-tahapan tertentu, namun seringkali penyebutan kondisi ontogenik daun sangat kualitatif, misalnya: daun yang baru tumbuh, daun muda, atau daun tua. Dalam penanggulangan penyakit, aplikasi stimulan, pengamatan fisiologis, dan kepentingan lain yang bersifat ilmiah diperlukan kesepakatan yang dapat dimengerti dan diterima oleh semua pihak untuk menghindari kesalahpahaman.

Studi mengenai perkembangan ontogenetik daun adalah topik yang menarik. Beberapa penelitian telah dilakukan terutama untuk mengetahui perubahan fisiologis daun (Miguel et al., 2007) dan efek lingkungan (Vinod et al., 2010). Fase perkembangan daun juga berkaitan dengan ketahanan terhadap serangan patogen yang dapat menyebabkan penyakit gugur daun. Selama periode perkembangannya, daun karet memiliki pola fisiologis tertentu. Beberapa klon memerlukan waktu lebih singkat untuk mencapai fase dewasa dibanding klon yang lain. Selain itu, masing-masing klon juga memiliki karakteristik anatomi seperti luas area daun, panjang internode(antar dua payung daun) dan panjang petiole yang berbeda pada kondisi lingkungan tertentu. Hal ini menunjukkan bahwa perkembangan ontogenetik daun dapat digunakan sebagai penanda awal kemampuan tanaman beradaptasi terhadap lingkungan sekitarnya.

Artikel ini menyajikan tahapan perkembangan daun karet yang diacu oleh peneliti terdahulu maupun saat ini, karakteristik fisiologis dan kaitan perkembangan daun dengan cekaman biotik (serangan patogen) dan abiotik (suhu rendah). Diharapkan dapat menjadi bahan kajian penelitian yang lebih mendalam terkait dengan beberapa aspek yang berhubungan seperti aplikasi stimulan dan pemupukan, dan serangan patogen. Dalam jangka panjang perkembangan ontogenik ini juga memungkinkan untuk dijadikan salah satu aspek penting dalam perakitan klon terkait dengan percepatan stadia pertumbuhan daun yang rentan terhadap serangan patogen.

\section{Tahapan Perkembangan Daun Karet}

Tanaman karet yang mengalami gugur daun akan segera membentuk daun baru yang tipis berwarna coklat tembaga dan berkilau. Selanjutnya, warna daun akan berubah dari hijau cerah menjadi hijau tua dalam 6-7 minggu setelah muncul (Vinod et al., 2010). Pertambahan ukuran daun hampir eksponensial pada fase awal perkembangan (Lieberei, 2007). Dalam praktek sehari-hari, tahapan perkembangan daun karet tidak dibedakan secara jelas, biasanya hanya dibedakan secara visual atau perkiraan umur daun tanpa menggunakan acuan yang standar berdasarkan perkembangan anatomi maupun morfologi.

Beberapa ilmuan mencoba mengidentifikasi tahapan perkembangan ontogenis daun karet. Samsuddin et al. (1978) mengunakan konsep 'leaf blade class' (LBC) yang didasari perubahan sudut helaian daun tengah terhadap tangkai daun. Untuk 
menentukan LBC, sudut maksimal $180^{\circ}$ dibagi dalam 9 tahap, masing-masing tahap memiliki interval $20^{\circ}$. LCB 1 memiliki interval sudut $0^{\circ}-20^{\circ}$, sedangkan LCB 9 memiliki interval $160^{\circ}-180^{\circ}$. Webster and Paardekooper (1989) mendukung konsep ini dengan menyatakan bahwa daun muda tersusun secara spiral, menggantung hampir paralel terhadap tangkai daun. Ketika bertambah dewasa sudutnya bertambah mendekati $180^{\circ}$, kondisi ini akan bertahan sampai daun mengalami gugur kembali. Lieberei (2007) menggunakan metode ini dalam penelitiannya mengenai penyakit gugur daun Amerika Selatan (South American Leaf Blight/SALB). Beberapa peneliti (Miguel et al., 2007; Vinod et al., 2010) mengembangkan fase daun tanaman karet oleh Djikman (1951) dan membedakan fase B menjadi B1 dan B2.

Tabel 1. Karakteristik daun pada masing-masing fase perkembangan daun karet.

\begin{tabular}{ccl}
\hline Fase & $\begin{array}{c}\text { Periode } \\
(\text { HSM })\end{array}$ & \multicolumn{1}{c}{ Morfologi } \\
\hline $\mathrm{A}$ & $1-6$ & $\begin{array}{l}\text { Helaian daun kecil, berwarna } \\
\text { merah tembaga, menggantung } \\
\text { vertikal }\end{array}$ \\
$\mathrm{B}$ & $7-16$ & $\begin{array}{l}\text { Helaian daun coklat kehijauan } \\
\text { mengkilap, tekstur lembut, } \\
\text { menggantung vertikal }\end{array}$ \\
$\mathrm{C}$ & $17-35$ & $\begin{array}{l}\text { Helaian daun hijau terang, } \\
\text { hampir berkembang sempurna, } \\
\text { lentur, menggantung vertikal }\end{array}$ \\
$\mathrm{D}$ & $>35$ & $\begin{array}{l}\text { Helaian daun berwarna hijau } \\
\text { sampai hijau gelap, kaku, } \\
\text { hampir horizontal terhadap } \\
\text { tangkai daun }\end{array}$ \\
&
\end{tabular}

Keterangan : - HSM : Hari setelah muncul

- Periode masing-masing fase kemungkinan berbeda di setiap lokasi dan klon

Sumber: Djikman (1951); Miguel et al. (2007)

Selama ini perkembangan stadia daun umumnya dinyatakan dalam bentuk kualitatif berdasarkan fisual terutama warna daun seperti daun tembaga, daun hijau muda, dan daun tua. Pembedaan stadia daun dalam beberapa fase yaitu A, B, C dan D yang digunakan oleh para ilmuan nampaknya dapat juga menjadi standar dalam menjelaskan stadia perkembangan daun dalam praktik di lapangan. Hal ini memungkinkan semua orang memiliki pengertian yang sama terhadap stadia daun yang dimaksud. Sebagai contoh, dalam penanggulangan penyakit gugur daun, aplikasi fungisida harus dilakukan pada stadia daun A atau paling lambat B. Jika fungisida disemprotkan pada stadia $\mathrm{C}$, maka efektivitasnya akan sangat rendah. 


\section{Karakteristik Fisiologi}

Selama perkembangannya, daun karet menunjukkan karakteristik fisiologi tertentu terutama yang berkaitan dengan proses fotosintesis. Penelitian Miguel et al. (2007) menunjukkan bahwa peningkatan signifikan kadar klorofil a,b, dan total klorofil pada fase
A sampai fase B2, selanjutnya terjadi penurunan pada fase $C$ kemudian meningkat secara signifikan pada fase D (Gambar 1a). Penurunan klorofil $a, b$, dan total klorofil antara fase B2 dan C terjadi bersamaan dengan laju ekspansi daun yang tinggi. Kadar klorofil menurun karena laju ekspansi daun lebih tinggi dibanding laju sintesis klorofil.

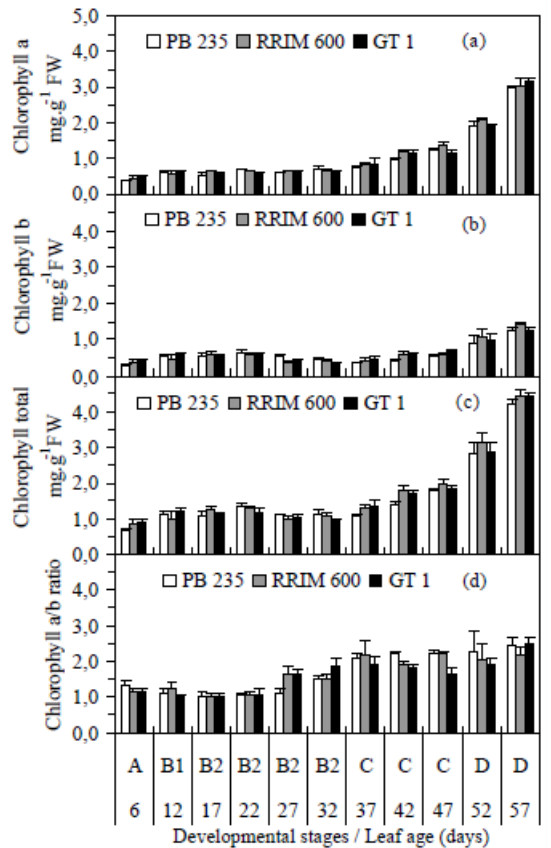

(a)

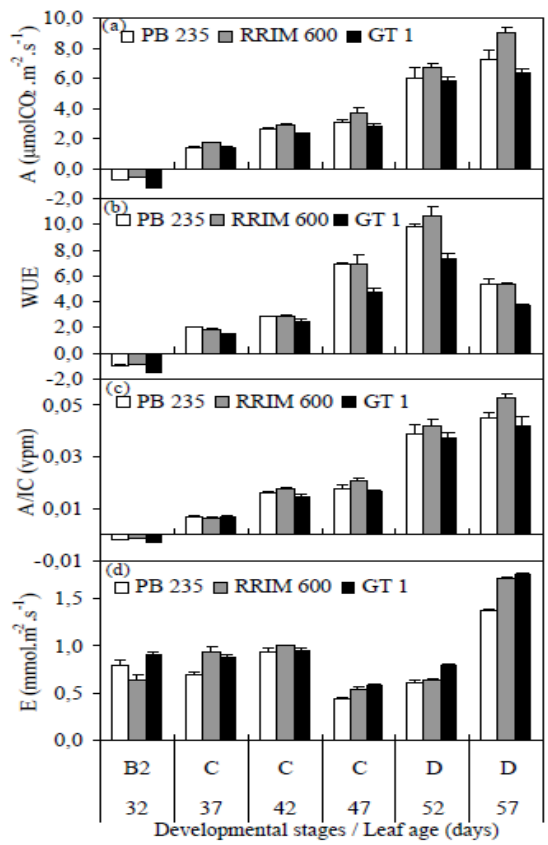

(b)

Gambar 1. a. Kadar klorofil $a$ (a), $b$ (b), total (c) dan rasio $a / b$ (d) selama perkembangan ontogenis daun

b. Fotosintesis bersih (A) (a), efisiensi penggunaan air (WUE) (b), efisiensi karboksilasi (A/IC) (c) dan transpirasi (E) (d) selama perkembangan ontogenis daun.

Sumber: Miguel et al. (2007)

Secara fisiologis fase A, B dan C bersifat sink (Lieberei, 2007) dengan proses pemanjangan dan multiplikasi sel yang cepat (Vinod et al., 2010), sedangkan fase D merupakan source yang telah memiliki karakteristik fisiologis dan struktural daun dewasa (Lieberei, 2007). Hasil penelitian Miguel et al. (2007) menunjukkan bahwa fotosintesis bersih pada fase B2 negatif, mulai positif pada fase $\mathrm{C}$ dan terus meningkat seiring pertambahan umur daun (Gambar 1b). Daun berperan sebagai sink yang kuat dan menggunakan cadangan fotosintat pada fase A sampai B2. Kemungkinan pada periode ini stomata belum terbentuk sempurna dan dalam proses transformasi selsel pra-stomata menjadi stomata fungsional. Ketika daun telah terbentuk sempurna, fotosintesis bersih mulai meningkat secara signifikan karena peningkatan kadar klorofil, efisiensi karboksilasi dan efisiensi penggunaan air. 


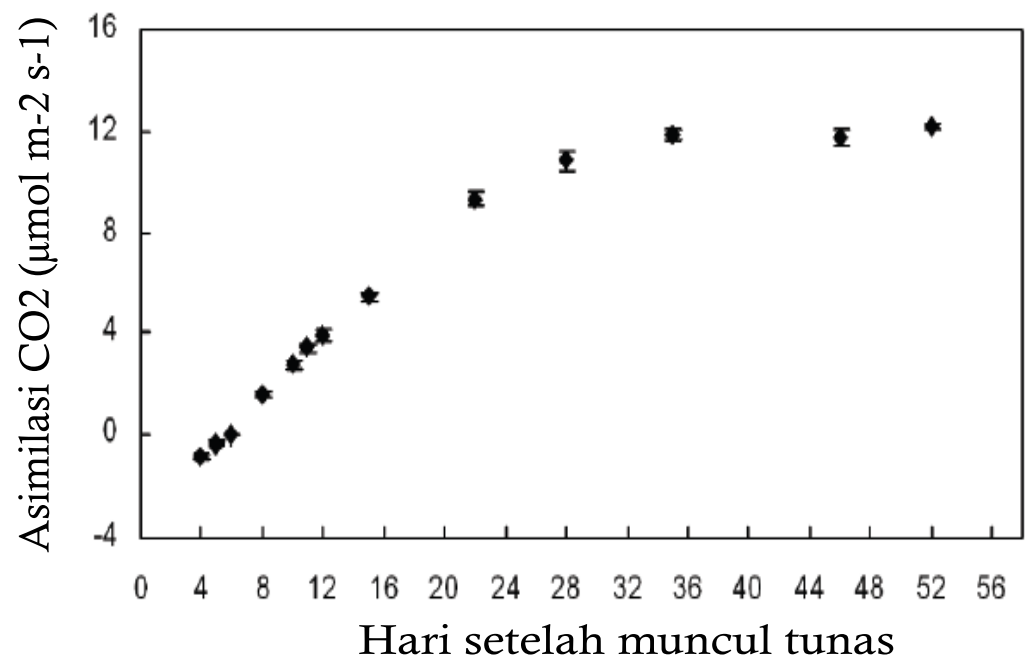

Gambar 2. Rata-rata laju asimilasi $\mathrm{CO}_{2}$ maksimum pada kondisi jenuh cahaya terhadap umur daun pada klon RRIM 600 (umur tanaman dua tahun) Sumber : Kositsup et al. (2010)

Kositsup et al. (2010) menyatakan bahwa laju asimilasi $\mathrm{CO}_{2}$ pada kondisi jenuh cahaya meningkat seiring umur daun dan mencapai maksimum sekitar umur 35 hari yaitu setelah fase B2, selanjutnya laju asimilasi cenderung stabil (Gambar 2). Selain fase ontogenetik daun, karakteristik fisiologis daun juga dipengaruhi oleh jarak tanam (Samsuddin and Impens, 1978), temperatur (Mai et al., 2009),tingkat naungan (Senevirathna et al., 2003), intensitas cahaya (Wang, 2014), hama penyakit (Daud et al., 2012), kadar air tanah (Monteny and Bargah, 1985), dan pemanenan lateks (Nugawela et al., 1990; Gunasekara et al., 2007).

Seiring bertambahnya umur daun, kadar hormon indoleacetic acid (IAA) yang berperan sebagai pendorong pertumbuhan menurun akibat meningkatnya aktivitas enzim IAA oksidase, sedangkan kadar hormon abscisic acid (ABA) tetap stabil. Ketidakseimbangan hormonal ini akan memicu proses senesen dan absisi yang menyebabkan daun menguning dan gugur (Chua, 1976). Dengan gugurnya daun berarti tanaman telah menyelesaikan satu siklus ontogenetik daun, selanjutnya tanaman akan segera memulai siklus selanjutnya dengan membentuk daundaun yang baru.
Kondisi daun sangat berpengaruh terhadap fluktuasi produksi lateks. Oktavia dan Lasminingsih (2010) mengamati produksi klon seri IRR pada beberapa kondisi tajuk yang dibedakan dalam lima fase yaitu fase 1 ketika muncul tanda-tanda daun menguning sampai kuning sebagian, fase 2 daun kuning menyeluruh dan sebagian sudah gugur, fase 3 semua daun telah gugur dan mulai muncul daun baru berwarna cokelat, fase 4 ketika daun berwarna hijau muda, dan fase 5 ketika daun berwarna hijau tua (fase dewasa). Hasil penelitian tersebut menunjukkan produksi lateks pada fase pembentukan daun baru (fase 3 ) nyata lebih rendah dibandingkan dengan fase daun penuh (fase 5) dan daun gugur (fase 3). Priyadarshan et al. (2001) menyatakan bahwa faktor iklim sangat mempengaruhi fenologi tanaman karet antara lain gugur daun, pembentukan daun baru, pembungaan, dan pembentukan buah, hal ini juga dipengaruhi oleh letak geografis terhadap khatulistiwa. Di wilayah utara Khatulistiwa produksi umumnya rendah pada periode Maret April, sedangkan di selatan Khatulistiwa pada September - Februari. 


\section{Respon Terhadap Kondisi Lingkungan}

Di wilayah yang mengalami periode kering yang tegas, periode gugur daun cenderung pendek dan pembentukan daun baru berlangsung cepat sehingga meminimalkan penurunan produksi. Sebaliknya di daerah yang periode keringnya tidak tegas, fase gugur daun dapat lebih panjang karena daun rontok tidak serentak. Jenis klon juga mempengaruhi pola gugur daun. Beberapa klon mengalami gugur daun bertahap yang simultan sehingga periode gugur daun tidak terlihat nyata, sedangkan beberapa klon lainnya sangat tegas sehingga tanaman tidak memiliki daun sama sekali dalam periode tertentu, namun kebanyakan adalah intermediet di antara dua pola ekstrim tersebut (Priyadarshan, 2011).

Masing-masing klon memiliki respon yang berbeda terhadap kondisi lingkungan setempat. Vinod et al. (2010) melaporkan bahwa klon RRIM 600, PB 5/51, SCATC 93/114, Haiken 1, dan GT pada kondisi suhu rendah di Timur Laut India menunjukkan fase perkembangan daun yang bervariasi (Tabel 2). Klon SCAT 93/114 menunjukkan perkembangan yang paling cepat mencapai fase dewasa (30,80 hari), sedangkan klon PB $5 / 51$ paling lambat (43,00 hari). Klon-klon lain mencapai kedewasaan daun relatif sama berkisar antara 33,30 sampai 37,30 hari.

Tabel 2. Rata-rata awal kemunculan masing-masing fase daun beberapa klon dari primodia hingga daun tua pada saat suhu rendah (bulan Pebruari) di Tripura (India).

\begin{tabular}{lccccc}
\hline \multirow{2}{*}{ Klon } & \multicolumn{5}{c}{$\begin{array}{c}\text { Fase perkembangan daun } \\
\text { (hari setelah muncul) }\end{array}$} \\
\cline { 2 - 6 } & $\mathrm{A}^{*}$ & $\mathrm{~B} 1$ & $\mathrm{~B} 2$ & $\mathrm{C}$ & $\mathrm{D}$ \\
\hline RRIM 600 & 5,70 & 14,20 & 22,20 & 29,30 & 37,30 \\
PB 5/51 & 7,00 & 15,80 & 24,00 & 34,80 & 43,00 \\
SCATC 93/114 & 1,80 & 7,80 & 13,80 & 25,20 & 30,80 \\
Haiken 1 & 4,30 & 12,20 & 19,30 & 27,80 & 33,30 \\
GT 1 & 5,00 & 13,80 & 20,80 & 30,00 & 35,30 \\
SE (d) & $0,29^{* *}$ & $0,68^{* *}$ & $0,35^{* *}$ & $0,73^{* *}$ & $1,82^{* *}$ \\
\hline
\end{tabular}

Catatan: * Fase A diukur mulai daun tengah teratas mencapai panjang $5 \mathrm{~mm}$ ** Berbeda nyata pada $p=0,05$

Sumber :Vinod et al. (2010)

Penelitian Vinod et al. (2010) menunjukkan bahwa transisi yang lebih cepat dari fase daun sink ke source pada tunas baru merupakan respon penting mengatasi cekaman suhu rendah. Klon-klon yang memiliki transisi yang cepat akan memiliki aparatus fotosintesis fungsional yang sempurna sebelum periode cekaman berakhir sehingga dapat mengisi cadangan makanan yang dikeluarkan selama periode gugur daun untuk mendukung pertumbuhan, diferensiasi, dan penguatan sel (Tabel 3). Oleh sebab itu, perkembangan daun yang cepat dari source ke sink merupakan indikator yang baik untuk menilai sifat toleran terhadap cekaman suhu dingin pada klon-klon karet. 
Tabel 3. Nilai rata-rata luas daun, panjang internod, dan panjang tangkai daun beberapa klon selama fase perkembangan ontogenetik.

\begin{tabular}{|c|c|c|c|c|c|c|c|}
\hline \multirow{2}{*}{ Klon } & \multirow{2}{*}{ Pengamatan } & \multicolumn{6}{|c|}{ Hari setelah tunas tumbuh (hari) } \\
\hline & & $0-7$ & $8-14$ & $15-21$ & $22-28$ & $29-35$ & $35-42$ \\
\hline \multicolumn{8}{|l|}{ Luas daun $\left(\mathrm{cm}^{2}\right)$} \\
\hline \multirow{2}{*}{ RRIM 600} & 1 & 0,05 & 0,05 & 10,70 & 40,70 & 56,10 & 56,10 \\
\hline & 2 & 0,07 & 0,48 & 11,14 & 43,90 & 58,31 & 60,01 \\
\hline \multirow[t]{2}{*}{$\mathrm{PB} 5 / 51$} & 1 & 0,02 & 0,11 & 1,30 & 12,50 & 29,00 & 30,90 \\
\hline & 2 & 0,07 & 0,20 & 1,92 & 17,25 & 39,79 & 41,49 \\
\hline \multirow[t]{2}{*}{ SCAT 93/114 } & 1 & 0,24 & 1,48 & 19,40 & 40,60 & 48,20 & 48,20 \\
\hline & 2 & 0,18 & 1,11 & 13,76 & 34,31 & 44,59 & 45,41 \\
\hline \multirow[t]{2}{*}{ Haiken 1} & 1 & 0,13 & 0,77 & 14,90 & 36,10 & 41,60 & 41,60 \\
\hline & 2 & 0,05 & 0,22 & 4,87 & 30,04 & 55,27 & 58,22 \\
\hline \multirow[t]{2}{*}{ GT 1} & 1 & 0.08 & 0,38 & 11,10 & 40,10 & 50,90 & 50,90 \\
\hline & 2 & 0,04 & 0,38 & 8,30 & 42,07 & 63,92 & 65,34 \\
\hline \multirow[t]{2}{*}{ SE (d) } & 1 & $0,01^{* *}$ & $0,05^{* *}$ & $0,60 * *$ & $3,31 * *$ & $2,16^{* *}$ & $1,43 * *$ \\
\hline & 2 & $0,05^{\text {** }}$ & $0,03 * *$ & 0,43 ** & 7,30 ** & $12,74^{*}$ & $13,69 *$ \\
\hline \multicolumn{8}{|c|}{ Panjang internod $(\mathrm{cm})$} \\
\hline \multirow[t]{2}{*}{ RRIM 600} & 1 & 0,55 & 0,95 & 2,12 & 2,51 & 2,72 & 2,72 \\
\hline & 2 & 0,33 & 0,53 & 1,42 & 2,02 & 2,12 & 2,12 \\
\hline \multirow[t]{2}{*}{ PB 5/51 } & 1 & 0,25 & 0,37 & 1,22 & 1,75 & 1,97 & 2,39 \\
\hline & 2 & 0,15 & 0,33 & 0,83 & 1,23 & 2,07 & 2,48 \\
\hline \multirow[t]{2}{*}{ SCAT 93/114 } & 1 & 0,82 & 1,70 & 2,32 & 3,80 & 3,85 & 3,99 \\
\hline & 2 & 0,67 & 1,37 & 2,78 & 3,03 & 3,18 & 3,27 \\
\hline \multirow[t]{2}{*}{ Haiken 1} & 1 & 0,45 & 0,80 & 1,57 & 1,92 & 2,10 & 2,15 \\
\hline & 2 & 0,32 & 0,52 & 1,33 & 2,72 & 2,85 & 2,90 \\
\hline \multirow[t]{2}{*}{ GT 1} & 1 & 0,42 & 0,77 & 1,99 & 2,62 & 3,10 & 3,20 \\
\hline & 2 & 0,25 & 0,43 & 0,82 & 1,25 & 1,40 & 1,45 \\
\hline \multirow[t]{2}{*}{ SE (d) } & 1 & $0,03^{* *}$ & $0,04^{* *}$ & $0,20 * *$ & $0,14^{* *}$ & $0,14^{* *}$ & $0,14^{* *}$ \\
\hline & 2 & $0,01^{* *}$ & 2,89 & $4,85^{*}$ & ns & ns & ns \\
\hline \multicolumn{8}{|c|}{ Panjang tangkai daun (cm) } \\
\hline \multirow[t]{2}{*}{ RRIM 600} & 1 & 1,03 & 2,52 & 11,70 & 15,77 & 16,12 & 16,20 \\
\hline & 2 & 1,32 & 2,75 & 8,00 & 11,67 & 11,82 & 11,88 \\
\hline \multirow[t]{2}{*}{$\mathrm{PB} 5 / 51$} & 1 & 0,34 & 0,65 & 4,40 & 8,52 & 9,77 & 9,80 \\
\hline & 2 & 0,57 & 1,52 & 6,28 & 11,93 & 14,33 & 15,47 \\
\hline \multirow[t]{2}{*}{ SCAT 93/114 } & 1 & 3,01 & 5,27 & 12,77 & 13,60 & 13,90 & 14,00 \\
\hline & 2 & 3,47 & 6,45 & 11,07 & 13,65 & 13,95 & 14,07 \\
\hline \multirow[t]{2}{*}{ Haiken 1} & 1 & 1,75 & 2,97 & 8,50 & 8,75 & 9,57 & 9,80 \\
\hline & 2 & 2,12 & 3,02 & 9,63 & 15,05 & 15,60 & 16,20 \\
\hline \multirow[t]{2}{*}{ GT 1} & 1 & 1,00 & 2,15 & 10.27 & 12,55 & 13,87 & 14,00 \\
\hline & 2 & 2,52 & 4,18 & 11,38 & 15,68 & 16,00 & 16,12 \\
\hline \multirow[t]{2}{*}{ SE (d) } & 1 & $0,04^{* *}$ & $0,14^{* *}$ & $0,24^{* *}$ & $0,72^{* *}$ & $0,81^{* *}$ & $0,76^{* *}$ \\
\hline & 2 & $0,59 * *$ & $1,09^{*}$ & $1,93^{*}$ & ns & ns & ns \\
\hline
\end{tabular}

Catatan: ns: tidak signifikan; *: signifikan pada $p=0.05 ;{ }^{* *}$ : signifikan pada $p=0.01$

Sumber: Vinod et al. (2010)

Faktor iklim seperti curah hujan, intensitas cahaya, suhu, dan kelembaban sangat mempengaruhi kecepatan perkembangan daun. Miguel et al. (2007) melakukan pengamatan pada klon PB 235, RRIM 600 dan GT 1 di Minas Greias, Brazil. Fase A diamati pada hari ke-6 setelah daun muncul, B1 pada hari ke-12, B2 pada hari ke$17,22,27$, dan 32 , fase $C$ pada hari ke-37, 42, dan 47 , sedangkan fase D pada hari ke-52, dan 57.

\section{Respon Terhadap Serangan Patogen}

Serangan patogen umumnya terjadi pada daun muda (fase A - C). Daun pada fase A $\mathrm{C}$ mengandung beberapa senyawa aromatik, tapi tidak mengandung lignin. Foto ultraviolet menunjukkan pada fase B dan C lignifikasi hanya terjadi pada pembuluh tracheid konduktif, sedangkan dinding sel tidak mengandung lignin sebagaimana ditemukan fada fase D. Pada daun dewasa, 
lignin akan menghambat penetrasi, perkembangan dan penyebaran pathogen dalam jaringan daun menyebabkan daun dewasa resisten terhadap serangan penyakit gugur daun (Gambar 3) (Lieberei, 2007). Pola yang sama sangat mungkin terjadi pada tanaman karet di Indonesia karena kondisi geografis dari daerah yang menjadi objek pengamatan merupakan daerah tropis (Brasil). Dari hasil pengamatan di lapangan, daun muda pada fase A-C sangat rentan terhadap serangan patogen tertentu yaitu jamur Colletotricum dan Oidium.

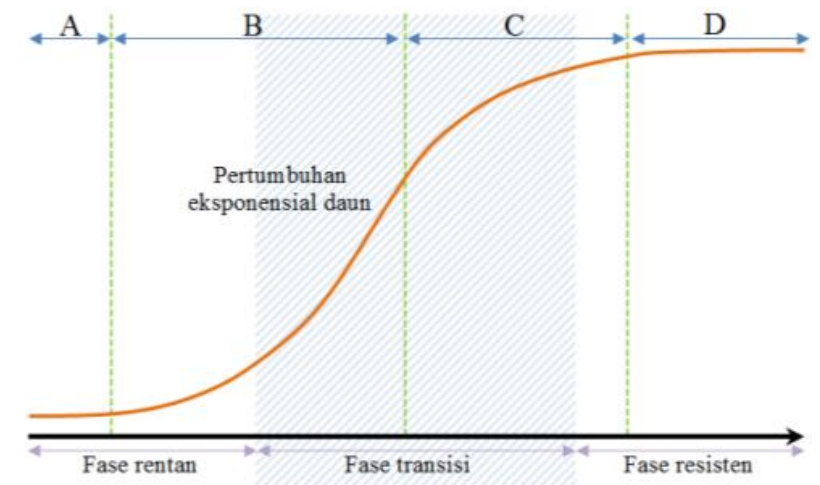

Gambar 3. Fase ketahanan tanaman terhadap penyakit gugur daun Amerika Selatan (South American Leafblight/SALB) berdasarkan perkembangan ontogenis daun Sumber:Lieberei (2007)

Lama fase rentan berbeda-beda antar klon karena sangat dipengaruhi oleh kecepatan pendewasaan daun. Webster and Paardekooper (1989) menyatakan bahwa jika pembentukan daun baru tidak tuntas (tidak mencapai fase dewasa) ketika lingkungan menjadi lembab (mulai musim penghujan), maka hama dan penyakit sangat rentan menyerang daun muda sehingga menyebabkan gugur daun sekunder. Dengan demikian dalam satu tahun dapat terjadi minimal dua kali gugur daun, sehingga fase tanaman karet tanpa daun menjadi lebih panjang dari seharusnya. Hal ini berakibat langsung terhadap lamanya periode dengan produksi lateks yang rendah. Oleh sebab itu, klon yang memiliki fase rentan yang lebih pendek memiliki peluang terhindar dari serangan penyakit daun dibandingkan dengan klon yang lebih lama mencapai fase dewasa.
Ketahanan daun terhadap penyakit juga dikaitkan dengan pelepasan senyawa asam sianida $(\mathrm{HCN})$. Prekusor senyawa $\mathrm{HCN}$ adalah linamarin glukosida dan lotaustralin. Pada jaringan yang rusak akibat infeksi penyakit, prekusor senyawa sianogenik dilepaskan bercampur dengan b-glikosidase. Kedua senyawa tersebut disimpan di tempat yang berbeda, b-glikosida diakumulasi dalam vakuola, sedangkan b-glikosidase disimpan di dinding sel (Selmar et al., 1988). Total prekusor sianogenik per bobot jaringan disebut $\mathrm{HCN}$ potensial (HCN-p) (Loyd dan Gray, 1970), sedangkan rata-rata pelepasan $\mathrm{HCN}$ disebut kapasitas $\mathrm{HCN}(\mathrm{HCN}-\mathrm{c})$. Pada tanaman karet, semakin tinggi HCN-c maka tanaman semakin rentan terhadap serangan patogen. Lieberei (1988) melaporkan bahwa kandungan HCN-p pada setiap fase perkembangan daun berbeda-beda. Secara umum, kadar HCN-p semakin tinggi pada awal (fase B dan A) perkembangan daun dan berkurang saat fase daun dewasa (D). 
Tabel 4. Nilai rata-rata luas daun, panjang internode, dan panjang tangkai daun beberapa klon Nilai kandungan $\mathrm{HCN}$-p berdasarkan pada setiap fase perkembangan daun karet.

\begin{tabular}{cc}
\hline Fase daun & $\begin{array}{c}\text { Kadar HCN-p } \\
\left(\mu \mathrm{mol} \mathrm{HCN} / \mathrm{cm}^{2} \text { luas daun }\right)\end{array}$ \\
\hline Tanaman 1 & 535 \\
A & 587 \\
B & 436 \\
C & 273 \\
D & \\
Tanaman 2 & 306 \\
A & 364 \\
B & 312 \\
D & 152 \\
\hline
\end{tabular}

Sumber: Lieberei (1988)

\section{Kesimpulan}

Daun karet memiliki karakteristik tersendiri selama perkembangan ontogenetik baik secara morfologi (ukuran, warna, dan sudut helai daun), maupun fisiologi (laju fotosintesis, laju transpirasi, dan akumulasi senyawa lignin). Perkembangan ontogenetik daun dapat digunakan sebagai penanda awal kemampuan tanaman beradaptasi terhadap lingkungan. Perubahan perkembangan daun yang cepat dari sink ke source merupakan indikator yang baik untuk menilai tingkat toleransi terhadap cekaman lingkungan dan patogen. Selanjutnya, penamaan fase A, B, $\mathrm{C}$ dan $\mathrm{D}$ dapat digunakan untuk penamaan stadia daun yang standar pada tanaman karet.

\section{Daftar Pustaka}

Chua, S.E. (1976). Role of growth promotor and growth inhibitor in foliar senescence and abscission of Hevea brasiliensis Muell Arg. Journal of the Rubber Research Institute of Malaysia, 24(4), 202 - 226.

Daud, R.D., Conforto, E.C., and Ferres, R.J.F. (2012). Change in leaf physiology caused by Calacarus heveae (Acari, Eriophyidae) on rubber tree. Experimental and Applied Acarology, 57, 127 - 137.

Dijkman, M.J. (1951). Hevea: Thirty years of research in the far fast. Coral Gables : University of Miami Press.
Gomez, J.B. (1982). Anatomy of Hevea and its influence on latex production. Kuala Lumpur : Malaysian Rubber Research and Developmet Board.

Gunasekara, H.K.I.K., de Costa, W.A.J.M., and Nugawela, E.A. (2007). Genotypic variation in canopy photosynthesis, leaf gas exchange characteristics and their response to tapping in rubber (Hevea brasiliensis). Experimental Agriculture, 43, $223-239$

Kositsup, B., Kasemsap, P., Thanisawanyangkura, S., Chairungsee, N., Satakhun, D., Teerawatanasuk, K., Ameglio, T., and Thaler, P. (2010). Effect of leaf age and position on lightsaturated $\mathrm{CO}_{2}$ assimilation rate, photosynthetic capacity, and stomatal conductance in rubber trees. Photosynthetica, 48(1), $67-78$.

Lieberei, R. (1988). Relationship of cyanogenic capacity $(\mathrm{HCN}-\mathrm{c})$ of the rubber tree Hevea brasiliensis to susceptibility to Microcyclus ulei, the agent causing South American leaf blight. Journal of Phytopathology, 122, 54-67.

Lieberei, R. (2007). South American leaf blight of the rubber tree (Hevea spp.) : New steps in plant domesticaton using physiological and molecular markers. Annals of Botany, 100, 1125-1142. doi $10.1093 / \mathrm{aob} / \mathrm{mcm} 133$. 
Loyd, R.C., and Gray, E. (1970). Amount and distribution of hydrocyanic acid potential during the life cycle of plants of three sorghum cultivars. Agronomy Journal, 62, 394-397.

Mai, J., Herbette, S., Vandame, M., Kositsup, B., Kasemsap, P., Cavaloc, E., Julien, J.L., Ameglio, T., and Drevet, P.R. (2009). Effect of chilling on photosynthesis and antioxidant enzymes in Hevea barasiliensis Muell. Arg. Trees, 23, $863-874$.

Martins, M.B.G., and Zieri, R. (2003). Leaf anatomy of rubber-tree clones. Scientia Agricola, 60(4), 709-713.

Miguel, A.A., de Oliveire, L.E.M., Cairo, P.A.R., and Oliveira, D.M. (2007). Photosynthetic behavior during ontogeny of rubber tree clones [Hevea brasiliensis (Wild. ex. Adr. de Juss.) Muell Arg.] in Lavras, MG. Science and Agrotechnology, 32(1), 91-97.

Monteny, B.A., and Barigah, S. (1985). Effect of leaf age and water deficit on the leaf photosynthetic rate of Hevea brasiliensis. Proceeding International Rubber Conference. Kuala Lumpur, October 1985.

Nugawela, A., and Aluthhewage, R.K. (1990). The effect of tapping on the $\mathrm{CO}_{2}$ assimilation rates of Hevea brasiliensis Muell. Arg. leaves. Journal Rubber Research Institute of Sri Lanka, 70, 45-51.

Oktavia, F., dan Lasminingsih, M. (2010). Pengaruh kondisi daun tanaman karet terhadap keragaman hasil sadap beberapa klon IRR. Jurnal Penelitian Karet, 28(2), 32 -40 .

Priyadarshan, P.M. (2011). Biology of Hevea Rubber. Preston: CAB International.

Priyadarshan, P.M., Sasikumar, S., and Goncalves, P.D.S. (2001). Phenological change in Hevea brasiliensis under differential geo-climates. The Planter, 77, $447-459$.

Righi, C.A. and Bernardes, M.S. (2008). The potential for increasing rubber production by matching tapping intensity to leaf area index. Agroforestry System, 72, 1-13. doi: 10.1007/s10457-007-9092-3.
Rifai, M.A. (2004). Kamus biologi. Jakarta : Balai Pustaka.

Samsuddin, Z., and Impens, I. (1978). Ecophysiological aspects of high density planting related to Hevea brasiliensis latex production. Acta Horticulturae, 65, 77-78. doi: 10.17660/ActaHortic.1978.65.11.

Samsuddin, Z., Abd. Rahman, M.K., and Impens, I. (1978). The development of leaf blade class concept for the characterisation of Hevea brasiliensis Muell. Arg. leaf stage. Journal of the Rubber Research Institute of Malaysia, 26(1), $1-5$.

Selmar, D., Lieberei, R., and Biehl, B. (1988). Mobilisation and utilisation of cyanogenic glycosides. Plant Physiology, 86, 711-716.

Senevirathna, A.M.W.K., Stirling, C.M., and Rodrigo, V.H.L. (2003). Growth, photosynthetic performance and shade adaptation of rubber (Hevea brasiliensis) grown in natural shade. Tree Physiology, 23, $705-712$.

Vinod, K.K.,. Meenattoor, J.R., Nanja Reddy, Y.A., Priyadarshan, P.M., and Chaudhuri, D. (2010). Ontogenetic variations in flus development are indicative of low temperature tolerance in Hevea brasiliensis clones. Annals of Forest Research, 53(2), 95 - 105.

Wang, L.F. (2014). Physiological and molecular responses to variation of light intensity in rubber tree (Hevea brasiliensis Muell Arg.). Plos One, 9(2), 1-10. doi:10.1371/journal.pone.0089514.

Webster, C.C., and Paardekooper, E.C. (1989). The botany of rubber tree. The genus Hevea. In Webster, C.C. and W.J. Baulkwill (Eds). Rubber. pp. 57 - 84 . London : Longman Scientific and Technical. 